\title{
Effect of Chlorine Dioxide, Polyhexa Methylene Guanidine and 1-Methylcyclopropene on Shelf Life of Banana (Musa paradisiacal L.) Fruit cv. Yelakki
}

\author{
Hemalatha $^{1}$, H.C. Krishna ${ }^{1}$, T.H. Shankarappa ${ }^{1,2} *$, G.S. Manjula ${ }^{1}$ and S.N. Shivakumar ${ }^{1}$ \\ ${ }^{1}$ Department of Postharvest Technology, College of Horticulture, University of Horticultural \\ Sciences Campus, GKVK, Bengaluru- 560065, India \\ ${ }^{2}$ Department of Agricultural Microbiology, College of Horticulture, Kolar, India \\ *Corresponding author
}

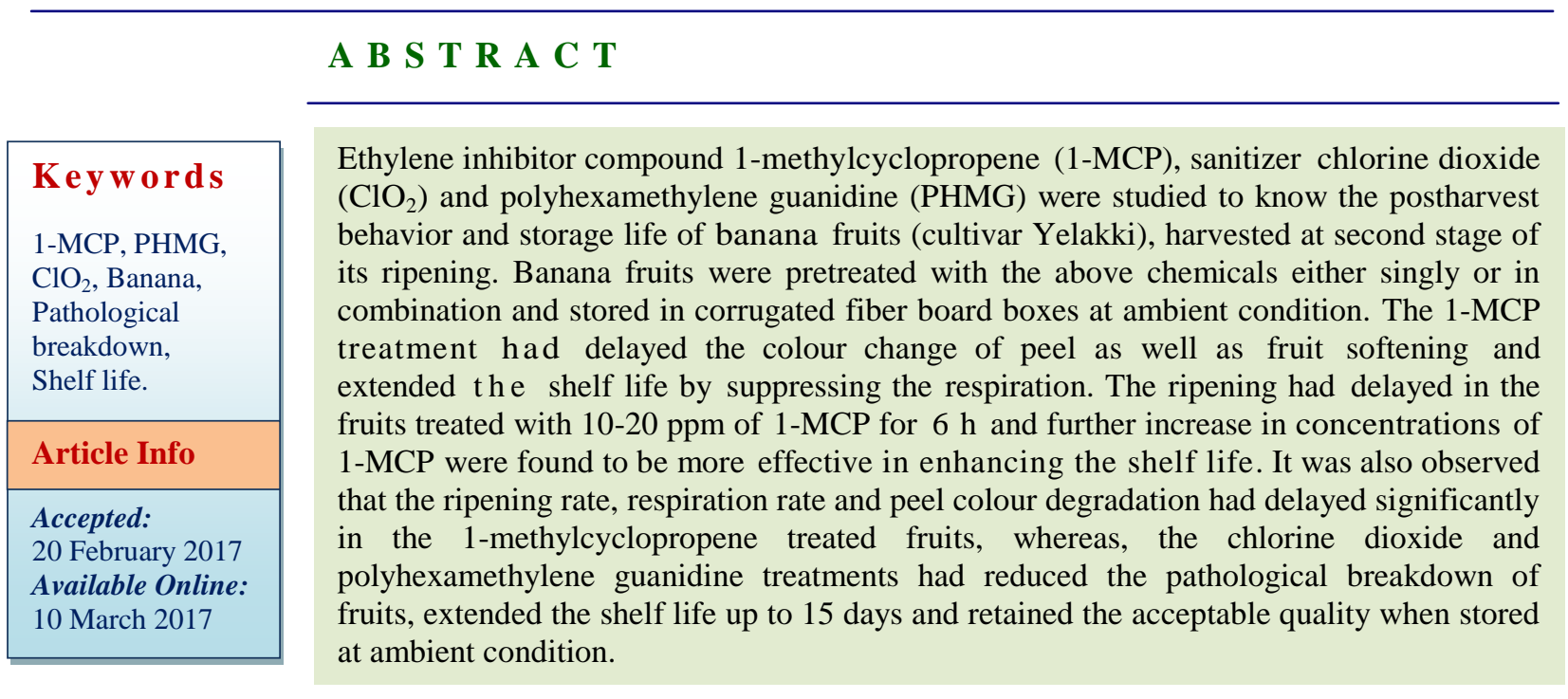

\section{Introduction}

Banana (Musa paradisiacal L.) is one of the most important, highly perishable climacteric fruit crops grown and consumed worldwide, they have a very short shelf life after harvest due to poor handling, storage, and transportation (Tock et al., 2010). Marketing of bananas successfully is one of the major challenges in under tropical conditions due to their limited shelf life. Bananas will have a marketing life of about 3-5 days once they are induced to ripen with exogenous ethylene commercially, depending on ethylene treatment conditions and the holding temperature after the treatment that eventually limits the long distance commercial transport (Gomer- Lim, 1997). Also, the premature ripening of banana has a negative effect on the shelf life and marketability of bananas. Prevention of buildup of ethylene around the produce is one of the methods followed at present to delay the ripening of bananas. This can be achieved through the use of agents such as 1-methylcyclopropene (1$\mathrm{MCP})$, chlorine dioxide $\left(\mathrm{ClO}_{2}\right)$ and polyhexamethylene guanidine (PHMG). 
The 1-MCP compound inhibits ripening by occupying irreversibly to ethylene-binding sites so that ethylene would not be able to bind and elicit subsequent signal transduction and translation in the ripening process (Villarreal et al., 2010). The use of 1-MCP is believed to be a new promising way of controlling ripening, senescence and other ethylene responses of climacteric fruits including banana. It is a gaseous, four-carbon cyclic olefin that inhibits ethylene action at the nano concentrations (Sisler and Serek, 1997). 1-MCP has a non-toxic mode of action, negligible residue and is active at very low concentrations (EPA, 2002). The complete release of $1-\mathrm{MCP}$ gas is mainly depends on temperature condition and it sometimes takes longer time at low temperatures.

Chlorine dioxide $\left(\mathrm{ClO}_{2}\right)$ is a powerful sanitizing agent that has broad and high germicidal activity. It is more stable and has a higher oxidizing capability than chlorine. Moreover, unlike chlorine, $\mathrm{ClO}_{2}$ does not react with nitrogen-containing compounds or ammonia, does not produce potentially carcinogenic byproducts and remains constant in a wide range of $\mathrm{pH} . \mathrm{ClO}_{2}$ is a legally permitted chemical for sanitizing fruits and vegetables (Tomás-Callejas et al., 2012). The $\mathrm{ClO}_{2}$ treatment has been proven to be a novel and effective non thermal technology for prolonging the shelf-life of fresh and fresh-cut produce (Lin et al., 2009). Similarly PHMG is a very efficient, multipurpose cationic polymer, used as a bactericide, disinfectant, preservative, biocide and fungicide (Mashat, 2016). It acts very fast and its single molecule nature works at least 20 to 1000 times more effective than silver and $\mathrm{H}_{2} \mathrm{O}_{2}$ alone. It decontaminates the ready to eat fruits and vegetables, extends the shelf life and protects the raw and postharvest fruits and vegetables without ill effects on human's skin (Carbo, 2010). Therefore, these chemicals were investigated on the shelf life and quality of harvested banana at ambient storage conditions.

\section{Materials and Methods}

The studies on quality and shelf life of banana cv. 'Yelakki' for the treatment viz. 1methylcyclopropene (1-MCP), chlorine dioxide $\left(\mathrm{ClO}_{2}\right)$ and polyhexamethylene guanidine (PHMG) was conducted at the Department of postharvest technology, College of horticulture, Bengaluru during the year 2016. The banana fruits were harvested at stage one of maturity (mature green fruits) manually based on criteria such as change in fruit skin colour from dark green to light green, reduced fruit detachment force and disappearance of angularity on the fingers, undamaged uniform fruits were selected. The randomly selected banana hands were treated with seven different treatments, viz. $\mathrm{T}_{1}-1$ MCP @ 10ppm + 200 ppm $\mathrm{ClO}_{2}, \mathrm{~T}_{2}-1 \mathrm{MCP}$ @ 15ppm + 200 ppm $\mathrm{ClO}_{2}, \mathrm{~T}_{3}-1 \mathrm{MCP} @$ $20 \mathrm{ppm}+200 \mathrm{ppm} \mathrm{ClO}_{2}, \mathrm{~T}_{4}-1 \mathrm{MCP} @$ $10 \mathrm{ppm}+\mathrm{PHMG} @ 2 \%, \mathrm{~T}_{5}-1 \mathrm{MCP} @$ $15 \mathrm{ppm}+\mathrm{PHMG} @ 2 \%, \mathrm{~T}_{6}-1 \mathrm{MCP} @$ 20ppm + PHMG @2\% and $\mathrm{T}_{7}-$ Control. Each treatment was replicated four times, packed in corrugated fiber board boxes and stored at ambient condition. The data was statistically analyzed.

The cut crown portion of banana bunch was dip treated in diluted lime water for a minute and then subjected for treatments. The chemical treatment was done such that the bananas were treated first with required quantity and concentration of freshly prepared $\mathrm{ClO}_{2}$ and PHMG solutions in distilled water. The fruits were dipped for 7 and 5 minutes respectively, air dried and then subjected for 1-MCP fumigation, where in tablet form of 1MCP was made into powder and 1-MCP concentrations of 10, 15 and 20 ppm solutions 
were prepared and fumigated in tight zip lock polyethylene covers. The treated fruits were removed from fumigation chamber after 6 hours of exposure and stored in ventilated CFB boxes.

The ripening rate was recorded by providing score at each stage of ripening (visually) and the co-efficient of ripening was calculated using formula. Where, Co-efficient of ripening $=\sum$ (No. of fruits at a particular ripening stage $\mathrm{x}$ its score / Total number of fruits. 1 to 7 score was allotted to measure the co-efficient of, where 1 indicates unripe stage and 7 indicates over ripe stage. The respiration rate was measured using the static headspace technique. The concentrations of $\mathrm{O}_{2}$ and $\mathrm{CO}_{2}$ were recorded in the headspace of the container by piercing the probe of an auto Oxygen/Carbon dioxide analyzer (Make: Quantek, Model: 902D Dual track) into the container through the septa fixed on the lid of container and reading was noted down from the instrument screen. The $\mathrm{CO}_{2}$ evolution was expressed in $\mathrm{mg} \mathrm{kg} \mathrm{h}^{-1}$. The firmness evaluation was carried out by taking whole fruit with skin and penetrating it with a $2 \mathrm{~mm}$ diameter cylindrical needle at a speed of 0.5 $\mathrm{mm} \mathrm{s}^{-1}$ with automatic return. Firmness was evaluated using a texture analyzer (Model: TA HD+, Make; Stable Microsystems, UK) equipped with a $50 \mathrm{~kg}$ load cell. The total soluble solids were measured by using a hand refractometer (Make: Erma Optical Works Ltd., Tokyo, Japan, $0-32^{\circ} \mathrm{B}$ range) and expressed as ${ }^{\circ}$ Brix (Anon., 1984). Fruit weight loss is measured through physiological loss of weight (\%). The fruits per cent spoilage was recorded visually. Sensory evaluation of fruits were assessed for the features viz. colour, taste, texture/body and absence of defects before and after storage period at initial and final observation by a panel of ten judges using composite scoring test. Finally shelf life in days was counted based on recorded observation.

\section{Results and Discussion}

The ripening rate of banana fruits, expressed as co-efficient of ripening is presented in figure 1. Rate of ripening of banana fruits during storage increased from harvest till the end of their storage life, irrespective of pretreatments given. However, there was a significant delay in the ripening rate of banana fruits treated with 1-MCP, PHMG and $\mathrm{ClO}_{2}$ in all the treatments when compared to untreated fruits. The untreated fruits recorded a ripening score of 6.54 on $8^{\text {th }}$ day of storage, while 1-MCP, PHMG and $\mathrm{ClO}_{2}$ treated fruits had remained in fourth stage of ripening at that time and reached full ripe stage ranging between 5.57 and 6.15 only after 14 days of storage.

The delayed ripening of banana treated with 1-MCP was due to its inhibition of ethylene action on ripening, 1-MCP is known to bind ethylene receptors in banana fruit, had transformed the fruits to have low respiration rate that would have enhanced the shelf life (Yueming et al., 1999; Wills et al., 2007; Golding, 1998). Over the time, the fruits would have synthesized new ethylene receptors thus returning the ethylene sensitivity.

The respiration rate of banana fruits treated with $1-\mathrm{MCP}$ with PHMG and $\mathrm{ClO}_{2}$ had shown a significantly lower rate of respiration than untreated fruits throughout their storage life (Fig.1). The respiration rate in untreated fruits had increased rapidly from initial $(0.02 \mathrm{mg}$ $\left.\mathrm{CO}_{2} \mathrm{~kg}^{-1} \mathrm{~h}^{-1}\right)$ to $8^{\text {th }}$ day of storage $(0.39 \mathrm{mg}$ $\mathrm{CO}_{2} \mathrm{~kg}^{-1} \mathrm{~h}^{-1}$ ) on the other hand, $1 \mathrm{MCP} @$ 20ppm and PHMG @ 2\% treated fruits had shown significantly lower respiration rate, $0.16 \mathrm{mg} \mathrm{CO}_{2} \mathrm{~kg}^{-1} \mathrm{~h}^{-1}$ followed by fruits treated with $1 \mathrm{MCP}$ at 20ppm and $200 \mathrm{ppm}$ $\mathrm{ClO}_{2}\left(0.17 \mathrm{mg} \mathrm{CO} \mathrm{kg}^{-1} \mathrm{~h}^{-1}\right)$ on $14^{\text {th }}$ day of storage. Bananas treated with 1-MCP had suppressed the respiration rate in the present 
study as reported by Clara et al., 2002; Eduardo et al., 2006; Zewter et al., 2012. The physiological loss in weight (PLW) of fruits treated with 1-MCP, PHMG and $\mathrm{ClO}_{2}$ was significantly lower than the untreated fruits at the end of the 8 days of storage (Fig. 2), where, untreated fruits had a PLW of $14.13 \%$, while, 1-MCP, PHMG and $\mathrm{ClO}_{2}$ treated fruits recorded PLW in the range of $5.49 \%$ to 6.00 $\%$. However, fruits treated with $20 \mathrm{ppm}$ of 1 MCP and 2\% PHMG recorded least PLW
$(9.13 \%)$. The maximum physiological weight loss in untreated fruits may be due to more loss of substrate, production of water and carbon dioxide; these are the products of respiration reaction. Treated fruits during the storage period recorded reduced respiration rate, might have led to less physical loss; keeping the vapour pressure surrounding the fruit uniform during the storage (Kader and Saltveit, 2003).

Fig.1 Effect of 1-MCP, PHMG and $\mathrm{ClO}_{2}$ on ripening rate (A) and respiration rate (B) of banana fruits stored at ambient condition
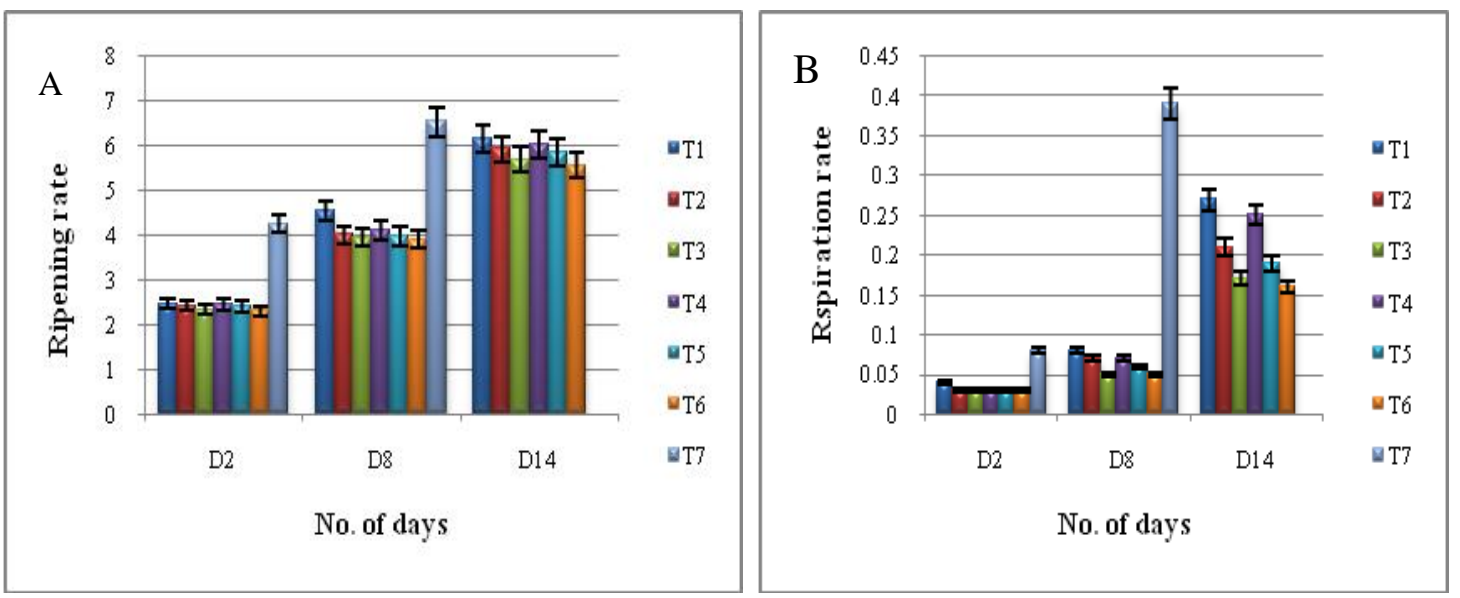

Fig.2 Effect of 1-MCP, PHMG and $\mathrm{ClO}_{2}$ on physiological loss in weight (A) and firmness (B) of banana fruits stored at ambient condition
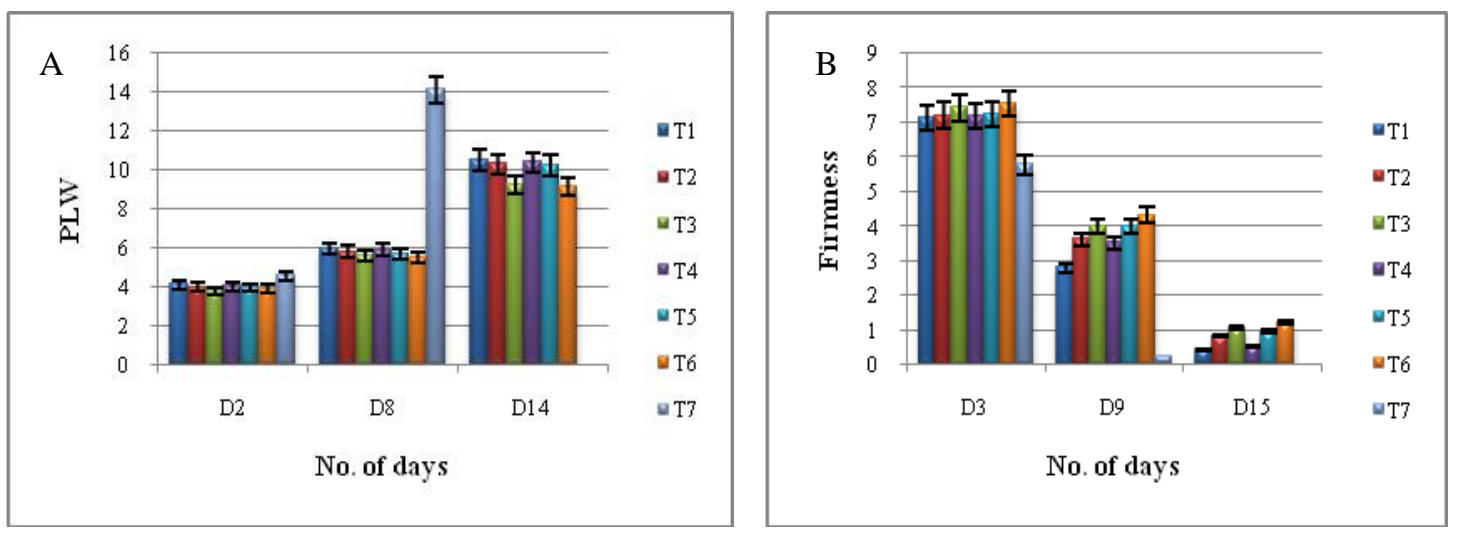
Fig.3 Effect of 1-MCP, PHMG and $\mathrm{ClO}_{2}$ on decay loss (A) and sensory evaluation (B) of banana fruits stored at ambient condition
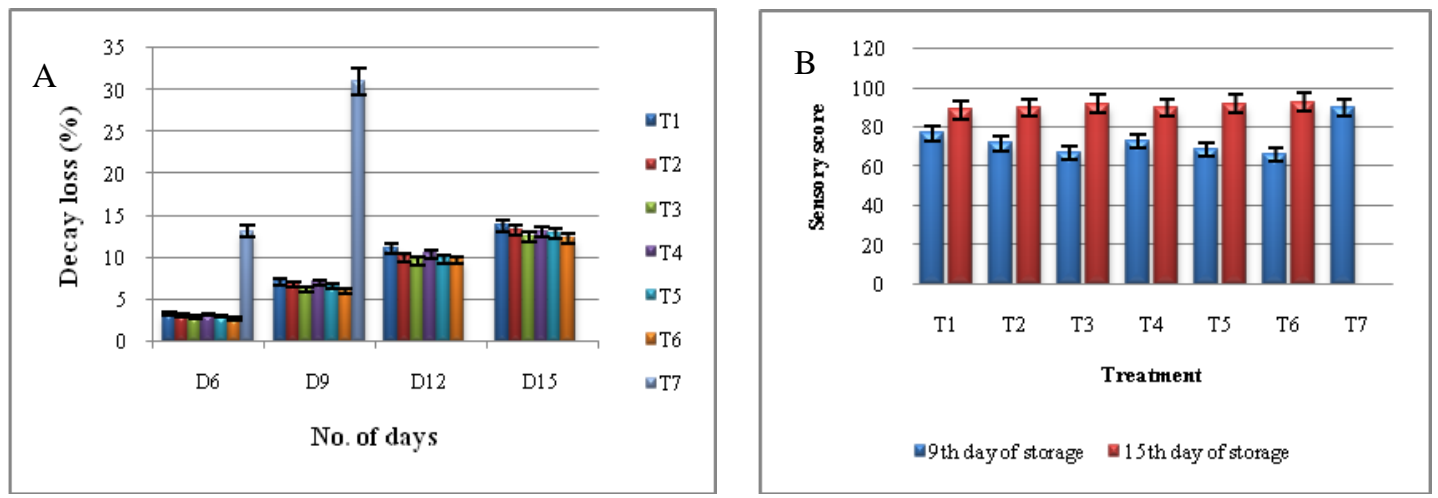

Fig.4 Effect of 1-MCP, PHMG and $\mathrm{ClO}_{2}$ on postharvest quality of Yelakki banana fruits stored at ambient condition on $1^{\text {st }}(\mathrm{A})$ and $15^{\text {th }}$ day $(\mathrm{B})$.
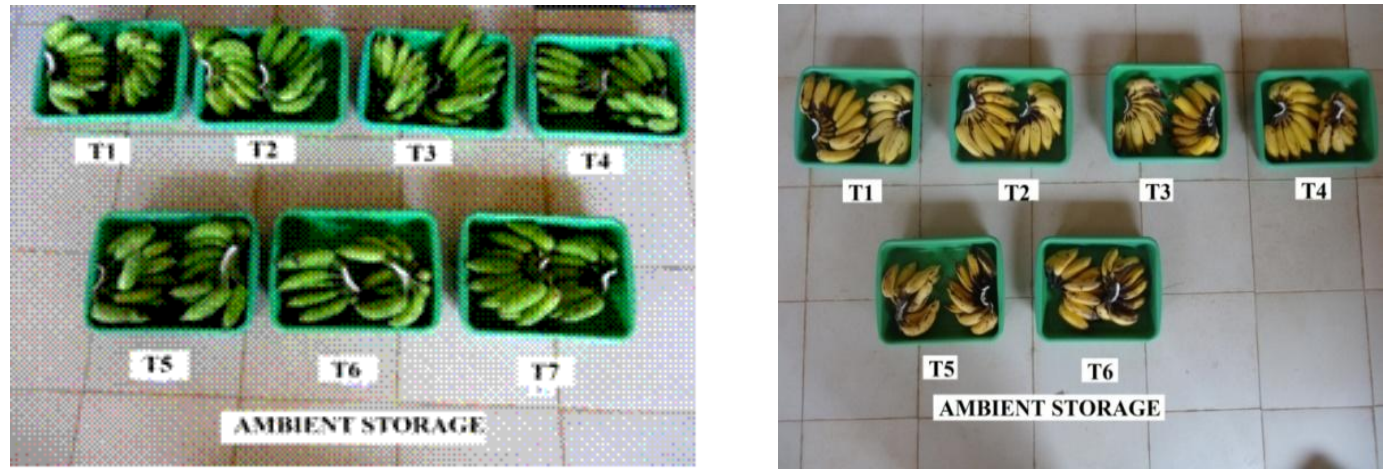

Table.1 Correlation studies on interaction effect of 1-MCP, PHMG and $\mathrm{ClO} 2$ on postharvest parameters with shelf life of banana fruit

\begin{tabular}{|c|c|c|c|c|c|c|c|c|c|c|c|c|c|c|}
\hline & 1 & 2 & 3 & 4 & 5 & 6 & 7 & 8 & 9 & 10 & 11 & 12 & 13 & 14 \\
\hline 1. Ripening rate & 1.00 & & & & & & & & & & & & & \\
\hline 2. Respiration & $1.00 * *$ & 1.00 & & & & & & & & & & & & \\
\hline 3. PLW & $0.99 * *$ & $0.99 * *$ & 1.00 & & & & & & & & & & & \\
\hline 4. Firmness & $-0.82^{* *}$ & $-.82 * *$ & $-.77 * *$ & $0.81 * *$ & $-.83 * *$ & 1.00 & & & & & & & & \\
\hline 5.Decay loss & $0.96 * *$ & $0.96 * *$ & $0.98^{* *}$ & $-.96^{* *}$ & $0.95 * *$ & $-.63 * *$ & $0.37 * *$ & $-.97 * *$ & $0.89^{* *}$ & $0.01 * *$ & $0.31^{* *}$ & $0.03 * *$ & 1.00 & \\
\hline 6. Shelf life & $\begin{array}{l}- \\
0.94 * *\end{array}$ & $\begin{array}{l}- \\
0.93 * *\end{array}$ & $\begin{array}{l}- \\
0.96 * *\end{array}$ & $0.93 * *$ & $\begin{array}{l}- \\
0.92 * *\end{array}$ & $0.57 * *$ & $\begin{array}{l}- \\
0.31 * *\end{array}$ & $0.95^{* *}$ & $\begin{array}{l}- \\
0.86^{* *}\end{array}$ & $0.07 * *$ & $\begin{array}{l}- \\
0.24 * *\end{array}$ & $0.10 * *$ & $\begin{array}{l}- \\
1.00^{* *}\end{array}$ & 1.00 \\
\hline
\end{tabular}

Firmness of banana fruits had decreased throughout the storage period irrespective of the treatment but magnitude of changes was slower in treated banana compared to untreated fruits
(Fig. 2). The fruits treated with $1 \mathrm{MCP}$ at 20ppm and PHMG at 2\% showed significantly higher value (4.33) while, untreated fruits registered minimum value for firmness $(0.24)$ 
during $9^{\text {th }}$ day of storage. The firmness of the fruit tissue at harvest was mainly due to the physical properties of the individual cell walls and the middle lamella which contains the cementing pectic material. As the fruit approached ripening the tissue became soft due to the degradation of the cell wall and the intercellular adhesive substances (Sterling, 1975). The softening of fruits observed was also due to synthesis of enzymes like polygalucturonase, methyl esterase, cellulases at climacteric peak of fruit (Pantastico, 1975). Study indicates that, the highest decay loss ranged from 13.18 to 31.04 per cent, recorded in untreated fruits on 6 to 9 day of storage (Fig. $3)$. The combination effect of 1-MCP, PHMG and $\mathrm{ClO}_{2}$ had shown significantly lower decay loss ranging between 6.03 to 7.15 per cent on $9^{\text {th }}$ day of storage compared to untreated fruits. The lower intensity of spoilage in 1-MCP, PHMG and $\mathrm{ClO}_{2}$ treated fruits were due to the antifungal and antimicrobial activity on fruits (Mohapatra et al., 2010), the antifungal and antibacterial activity was established through the minimal inhibitory concentrations (Carbo et al., 2010).

It is evident from the sensory scores presented in figure 3 that, untreated fruits had higher total sensory scores (90) followed by the treated fruits on $9^{\text {th }}$ day of storage. After 15 days of storage, eating quality of 1-MCP, PHMG and $\mathrm{ClO}_{2}$ treated fruits were found to be acceptable and had sensory scores between 89 and 93 Banana treated with 1-MCP, PHMG and $\mathrm{ClO}_{2}$ had shown a significant increase in storage life, 15 days in all the treatments compared to untreated fruits. The storage life (days to reach consumer acceptable quality) of untreated fruits were found to be 9 days. However, 1-MCP, PHMG and $\mathrm{ClO}_{2}$ treated fruits took 15 days to reach full ripe stage with enhanced 6 days of life over control (Fig. 4). This extension of storage period was due to the delay in the ripening process, reduced biochemical changes, reduced microbial load caused by ethylene inhibition which also suppressed the respiration rate during storage (Mohapatra et al., 2010). It was observed from the correlation studies that the shelf life was dependent on factors such as ripening rate, respiration PLW, firmness (Table 1). The positive correlation observed was higher than negative correlation, the dependent variable was shelf life and it was related to many different independent parameters. Shelf life exhibited positive and significant association with ripening rate, respiration rate, physiological loss in weight, decay and loss, while, shelf life exhibited negative and significant association with the firmness of the banana fruit. This is in confirmation with the findings of (Mohapatra et al., 2010).

In conclusion, the storage life of banana fruits cv. Yelakki can be extended up to 15 days, if pre-treated with 1-MCP in ambient condition $\left(25 \pm 2^{\circ} \mathrm{C}\right.$ and $\left.52 \pm 2 \% \mathrm{RH}\right)$. The decay loss can be minimized when treated with PHMG and $\mathrm{ClO}_{2}$. The best treatment for extending the shelf life of yelakki banana was combination of 1 MCP (20 ppm) and PHMG (2\%) followed by 1 MCP (20 ppm) and $\mathrm{ClO}_{2}$ (200 ppm). These two treatments had increased the storage life besides reducing the microbial spoilage during storage period. The 1-MCP treated fruits had shown delayed ripening, reduced respiration and retained higher firmness.

\section{References}

Clara, P., Eduardo, V., Vilas, B., Mohamed, B., Kader, A. 2002. Variability in responses of partially ripe bananas to 1methylcyclopropene. Postharvest Biol. Technol., 28: 75-85.

Corbo, M.R., Speranza, B., Campaniello, D., D’Amato, D., Sinigaglia, M. 2010. Freshcut fruits preservation: current status and emerging technologies. In: Current Research, Technology and Education topics in Microbiology and Microbial Biotechnology. Ed. Mendez Vilas, A. Formatex Res. Center, pp. 1143-1154.

Eduardo, V., Boas, B.B., Kader, A.A. 2006. Effect of atmospheric modification, 1MCP and chemicals on quality of freshcut banana. Postharvest Biol. Technol., 39: $155-162$. 
EPA. 2002. Guidelines for Ensuring and Maximizing the Quality, Objectivity, Utility, and Integrity of Information Disseminated by the Environmental Protection Agency: U.S. Environmental Protection Agency Office of Environmental Information, Pennsylvania Avenue, NW Washington, DC. pp19.

Golding, J.B., Shearer, D., Wyllie, S.G., Mcglasson, W.B. 1998. Application of 1MCP and propylene to identify ethylenedependent ripening processes in mature banana fruit. Postharvest Biol. Technol., 14: 87-98.

Gomer-Lim, M.A. 1997. Post-harvest physiology. In: The Mango: Botany, production and uses (Ed.): Litz, R.E. $\mathrm{CAB}$ International, New York pp. 425446.

Kader, A.A., Saltveit, M.E. 2003. Respiration and exchange. In: Postharvest physiology and pathology of vegetables ( $2^{\text {nd }}$ ed.) Ed. Bartz J. A., Brecht, J. K. Marcel Dekker Inc., New York, USA. pp 7-23.

Lin, Z., Zhong, S., Grierson, D. 2009. Recent advances in ethylene research. J. Exp. Bot., 60: 3311-3336.

Mashat, B.H. 2016. Polyhexamethylene Biguanide Hydrochloride: Features and applications. British J. Environ. Sci., 4(1): 49-55.

Mohapatra, D., Mishra, S., Sutar, N. 2010. Banana post harvest practices: Current status and future prospects- A review. Agric. Rev., 31(1): 56 - 62, 2010.

Pantastico, E.B. 1975. Postharvest physiology, handling and utilization of tropical and subtropical fruits and vegetables. The AVI publishing Co., West port, connection, USA, pp. 86-90.
Sisler, E.C., Serek, M. 1997. Inhibition of ethylene responses in plants at the receptor level: recent developments. Physiol. Pl., 100: 577-582.

Sterling, C. 1975. Anatomy of toughness in plant tissue in postharvest biology and handling of fruits and vegetables. AVI pub. Co. Westport Connecticut, USA.

Tock, J.Y., Lai, C.L., Lee, K.T., Tan, K.T., Bhatia, S. 2010. Banana biomass as potential renewable energy resource: A Malaysian case study. Renewable and Sustainable Energy Reviews, 14(2): 798-805.

Tomás-Callejas, A., López-Gálvez, F., Sbodio, A., Artés, F., Artés-Hernández, F., Suslow, T. V., 2012. Chlorine dioxide and chlorine effectiveness to prevent Escherichia coli O157:H7 and Salmonella cross-contamination on fresh-cut red chard. Food Control, 23: 325-332.

Villarreal, N.M., Bustamante, C.A., Civello, P.M., Martínez, G.A. 2010. Effect of ethylene and 1-MCP treatments on strawberry fruit ripening. J. Sci. Food Agric., 90(4): 683-689.

Wills, R.B., Lim, J.S., Greenfield, H. 2007. Changes in chemical composition of 'Cavendish' banana (Musa acuminate) during ripening. J. Food Biochem., 8: 6977.

Yueming, J., Daryl, C.J., Andrew, J.M. 1999. Extension of the shelf life of banana fruit by 1 - MCP in combination with polyethylene bags. Postharvest biol. Technol., 16: 187-193.

Zewter, A., Woldetsadik, K., Workneh, T.S. 2012. Effect of 1- $\mathrm{MCP}, \mathrm{KMnO}_{4}$ and packaging on quality of banana. African J. Agri., 7(16): 2425-2437.

\section{How to cite this article:}

Hemalatha, H.C. Krishna, T.H. Shankarappa, G.S. Manjula and Shivakumar, S.N. 2017. Effect of Chlorine Dioxide, Polyhexa Methylene Guanidine and 1-Methylcyclopropene on Shelf Life of Banana (Musa paradisiacal L.) Fruit cv. Yelakki. Int.J.Curr.Microbiol.App.Sci. 6(3): 1325-1331. doi: https://doi.org/10.20546/ijcmas.2017.603.153 